\title{
Status gizi dan motivasi belajar sebagai faktor risiko terhadap kemampuan kognitif anak sekolah dasar di daerah endemik GAKY
}

\author{
Nutritional status and learning motivation as risk factor s of cognitive ability of elementary school \\ students in iodine deficiency disorder (IDD) endemic area
}

Dian Agnesia', Toto Sudargo², Untung Supariadi Widodo ${ }^{3}$

\begin{abstract}
Background: More than 200 million children under 5 years old in developing countries are not fulfilled its development potential. Child potential development is influenced by several factors, such as biological factors, psychosocial, physical, social, culture, and socio-economic . People living in iodine deficiency area have intelligent quotient (IQ) up to 13.5 point lower than those living in the area with sufficient iodine. The result of iodinized salt monitored by Sleman District Health Office showed total goitre rate (TGR) of school children in Subdistrict of Cangkringan, District of Sleman was 39.5, which was categorized as severe iodine deficiency.

Objective: To identify nutritional status (anthropometry), academic achievement, and learning motivation as risk factors of cognitive ability of elementary children in IDD endemic area .

Method: The study used case control design. Samples consisted of 107 children with cognitive ability below average (score $I Q<90)$ as cases and 198 children with cognitive ability above average (score $I Q \geq 90$ ) as controls. Data of cognitive ability were obtained through culture fair intelligence test (CFIT), anthropometric assessment for nutritional status, clean score of Indonesian and mathematics for academic achievement, and questionnaire for learning motivation of children. Data were processed descriptively and analytically using chi-square and t-test.

Result: The prevalence of short nutritional status was $25.9 \%$. There was significant association between nutritional status (height/age) $(p=0.46)$, learning motivation $(p=0.03)$, and academic achievement (Indonesian, $p=0.00$, mathematics, $p=0.000$ ), and cognitive ability. There was no association between nutritional status (Body Mass Index/age) and cognitive ability $(p=0.109)$. Children with short nutrition status had risk 1.7 times greater for lower cognitive ability. Children with low learning motivation had risk 3.3 times greater for low cognitive ability.

Conclusion: Children with cognitive ability above average had nutritional status (height/ age), learning motivation, and academic achievement (Indonesia and mathematics) better than those with cognitive ability below average.
\end{abstract}

KEYWORDS: cognitive, nutritionl status, learning motivation, academic achievement, iodine deficiency disorder

\begin{abstract}
ABSTRAK
Latar belakang: Lebih dari 200 juta anak di bawah 5 tahun di negara berkembang tidak terpenuhi potensi perkembangannya. Potensi perkembangan anak dipengaruhi oleh beberapa faktor, yaitu faktor biologis, psikososial, fisik, sosial budaya serta, sosial ekonomi. Masyarakat yang tinggal di daerah defisiensi iodium memiliki intelligent quotient (IQ) hingga 13,5 point lebih rendah dibandingkan masyarakat yang tinggal di daerah cukup yodium. Hasil pemantauan garam beryodium oleh Dinas Kesehatan Sleman menunjukkan
\end{abstract}

\footnotetext{
${ }^{1}$ Sekolah Tinggi Kesehatan Widya Cipta Husada Kepanjen-Malang, e-mail: agnesia.d@gmail.com

${ }^{2}$ Prodi Gizi Kesehatan Fakultas Kedokteran Universitas Gadjah Mada, Jl. Farmako, Sekip Utara, Yogyakarta 55281, e-mail: totosud@indosat.net.id

${ }^{3}$ Balai GAKY, Kapling Jayan, Borobudur, Magelang, Jawa Tengah
} 
total goitre rate (TGR) anak sekolah di Kecamatan Cangkringan Kabupaten Sleman adalah 39,5\%, yang tergolong dalam endemik berat.

Tujuan: Mengetahui bahwa status gizi (antropometri), prestasi belajar, dan motivasi belajar sebagai faktor risiko terhadap kemampuan kognitif anak sekolah dasar di daerah endemik GAKY.

Metode: Jenis penelitian adalah studi kasus kontrol. Jumlah subjek penelitian yaitu kelompok kasus 107 anak dengan kemampuan kognitif di bawah rata-rata (skor IQ<90) dan kontrol 198 anak dengan kemampuan kognitif di atas rata-rata (skor $I Q \geq 90$ ). Pengumpulan data kemampuan kognitif dengan menggunakan culture fair intelligence test (CFIT), pengukuran antropometri untuk status gizi, nilai murni Bahasa Indonesia dan matematika untuk prestasi belajar dan kuesioner untuk motivasi belajar anak. Data diolah secara deskriptif analitik menggunakan uji chi-square dan uji beda t-test.

Hasil: Prevalensi status gizi pendek sebesar 25,9\%. Terdapat hubungan signifikan antara status gizi $(T B / U)(p=0,046)$, motivasi belajar $(p=0,03)$, dan prestasi belajar (Bahasa Indonesia, $p=0,00$, matematika, $p=0,00)$ dengan kemampuan kognitif. Tidak terdapat hubungan signifikan antara status gizi (IMT/U) dengan kemampuan kognitif $(p=0,109)$. Anak dengan status gizi pendek berisiko 1,7 kali memiliki kemampuan kognitif di bawah rata-rata daripada anak normal. Anak dengan motivasi rendah berisiko 3,3 kali memiliki kemampuan kognitif di bawah rata-rata .

Kesimpulan: Anak dengan kemampuan kognitif di atas rata-rata memiliki status gizi, motivasi belajar, dan prestasi belajar (Bahasa Indonesia maupun matematika) yang lebih baik daripada yang memiliki kemampuan kognitif di bawah rata-rata.

KATA KUNCI: kognitif , status gizi, motivasi belajar, prestasi belajar, endemik GAKY

\section{PENDAHULUAN}

Perkembangan anak dan masalah gizi merupakan masalah yang saling berkaitan di negara berkembang. Sampai saat ini gizi kurang masih menjadi masalah nasional di Indonesia (1). Lebih dari 200 juta anak di bawah 5 tahun di negara berkembang tidak terpenuhi potensi perkembangannya. Perkembangan anak meliputi sensor-motorik, kognitif, dan emosi (2). Beberapa faktor yang mempengaruhi potensi perkembangan anak di antaranya faktor biologis, psikososial, fisik, sosial budaya, serta sosial ekonomi (3).

Status gizi merupakan salah satu bagian dari faktor biologis untuk anak usia sekolah, termasuk kelompok rentan gizi, selain bayi, balita, remaja, ibu hamil, ibu menyusui, dan lansia (4). Sekitar $50 \%$ penduduk Indonesia atau lebih dari 100 juta jiwa mengalami masalah kekurangan gizi. Masalah gizi kurang seringkali luput dari pengamatan dan tidak cepat ditanggulangi, sehingga memunculkan masalah yang lebih besar. Dampak kekurangan gizi akan terlihat pada rendahnya partisipasi sekolah dan rendahnya pendidikan (5).

Sebuah penelitian di Guatemala tahun 1972 (6), menemukan bahwa asupan nutrisi dan faktor sosial sangat mempengaruhi perkembangan kognitif.
Empat defisiensi mikronutrien seperti yodium, zat besi, seng, dan vitamin B12 berhubungan dengan kemampuan kognitif anak (7). Risiko dari defisiensi vitamin dan mineral ini berhubungan dengan perkembangan intelektual yang rendah dan kemampuan kognitif, serta menurunkan sistem imun tubuh (8). Hal ini sejalan dengan penelitian di Sri Lanka tahun 2003 (9) yang menemukan bahwa anak-anak kurang gizi memiliki kemampuan kognitif yang lebih rendah dan hal ini juga didukung oleh tingkat ketidakhadiran siswa di sekolah.

Beberapa penelitian terdahulu menyebutkan bahwa anak yang tinggal di daerah defisiensi yodium ternyata memiliki intelligent quotient (IQ) 13,5 point lebih rendah dibandingkan anak-anak yang tinggal di daerah cukup yodium (10). Defisiensi yodium sangat berpengaruh terhadap kualitas sumber daya manusia, meliputi tumbuh kembang dan perkembangan otak. Pada tahun 1999, World Health Organization (WHO) mengestimasikan 740 juta orang menderita penyakit gondok, yaitu sebanyak $13 \%$ dari populasi dunia (11).

Kemampuan kognitif pada penelitian ini diukur menggunakan tes culture fair intelligent test (CFIT) yang hasilnya berupa skor IQ (12), sedangkan untuk melihat indikator pencapaian prestasi belajar siswa 
di sekolah akan dilihat dari nilai Bahasa Indonesia dan matematika. Penelitian yang dilakukan di Kabupaten Malang tahun 2003 menemukan bahwa anak-anak di daerah endemik GAKY memiliki IQ di bawah 80 serta memiliki gangguan kemampuan bicara, menulis, dan berhitung (13). Penelitian lain di India tahun menemukan bahwa anak-anak di daerah defisiensi yodium akan lemah pada kemampuan kognitif terutama verbal, perceptual , ingatan, dan matematika serta memiliki motivasi belajar yang rendah (14).

Motivasi sebagai salah satu faktor psikososial dalam perkembangan kognitif anak menjadi sangat penting, karena kesuksesan seorang anak di sekolah secara umum tergantung pada faktor motivasi (15). Motivasi berhubungan positif dengan prestasi belajar, kemampuan intelektual, dan persepsi kompetensi, serta berbanding terbalik dengan kecemasan akademis (16). Proses kognitif sendiri terjadi melalui beberapa fase yang diawali oleh fase motivasi, konsentrasi, pengolahan informasi, menggali informasi, prestasi, dan umpan balik (17). Motivasi merupakan elemen penting dalam perkembangan kognitif karena berperan dalam mengembangkan pengetahuan dan keterampilan anak (18).

Penelitian ini dilakukan di Kecamatan Cangkringan tahun 2010 dan didapatkan total goitre rate (TGR) anak sekolah adalah $39,5 \%$, yang termasuk ke dalam kategori daerah endemik berat (19). Menurut hasil Survei Nasional Evaluasi Intensifikasi Penanggulangan GAKY pada tahun 2003, Yogyakarta termasuk dalam provinsi dengan proporsi konsumsi garam rumah tangga yang rendah $(<40 \%)(20)$. Berdasarkan uraian latar belakang tersebut, maka peneliti tertarik untuk meneliti mengenai status gizi, motivasi belajar, dan prestasi belajar sebagai faktor risiko terhadap kemampuan kognitif anak sekolah dasar di daerah endemik GAKY.

\section{BAHAN DAN METODE}

Penelitian ini merupakan penelitian observasional analitik yang menggunakan rancangan kasus-kontrol. Penelitian dilaksanakan pada bulan Mei hingga Agustus 2010 di SD
Kecamatan Cangkringan Provinsi Daerah Istimewa Yogyakarta.

Penetapan SD dipilih berdasarkan SD dengan TGR tertinggi yang berjumlah $6 \mathrm{SD}$, untuk menentukan sampel penelitian. Teknik pengambilan sampel yang digunakan adalah probability sampling dengan cara proportionate random sampling. Dari 6 SD yang menjadi populasi, dilakukan skrining menggunakan tes kemampuan kognitif CFIT. Anakanak dengan kemampuan kognitif di bawah ratarata (skor IQ <90) dikelompokan sebagai kasus, kemudian sebagai kelompok kontrol yaitu anakanak yang memiliki kemampuan kognitif di atas rata-rata (skor IQ $\geq 90$ ). Sampel pada penelitian ini sebanyak 305 anak yang terbagi dalam 107 anak sebagai kelompok kasus dan 198 anak sebagai kelompok kontrol, dengan memperhatikan kriteria inklusi, yaitu yang berusia 8-14 tahun, tinggal di daerah penelitian selama minimal 6 bulan, serta bersedia diikutkan dalam penelitian.

Data yang diambil meliputi karakteristik subjek meliputi nama, umur, jenis kelamin, dan motivasi belajar anak didapatkan dengan wawancara menggunakan kuesioner. Status gizi anak diukur secara antropometri dan dikategorikan berdasarkan standar baku dengan indeks tinggi badan berdasarkan umur (TB/U) maupun indeks massa tubuh berdasarkan umur (IMT/U ). Berat badan didapatkan menggunakan timbangan injak digital scale. Tinggi badan didapatkan dengan menggunakan microtoise. Nilai mata pelajaran Bahasa Indonesia dan matematika didapatkan dari nilai tes kendali mutu (TKM) semester terakhir, sedangkan kemampuan kognitif dilakukan oleh seorang $p$ sikolog terakreditasi dari Balai Penelitian GAKY. Kemampuan kognitif dinilai menggunakan tes CFIT.

Uji validitas dan reliabilitas kuesioner motivasi belajar diujikan kepada 30 anak sekolah dasar kelas 3, 4, dan 5 yang berusia 8-14 tahun. SD yang digunakan untuk uji coba kuesioner adalah SD yang masih berada di wilayah penelitian dan memiliki karakteristik yang hampir sama dengan sampel penelitian dengan memperhatikan segi tenaga, biaya, dan waktu. Berdasarkan uji reliabilitas, diketahui bahwa nilai alpha cronbach's kuesioner 
motivasi belajar adalah 0,815. Dengan jumlah sampel 30 anak, maka didapatkan angka $r$ tabel 0,239 . Berdasarkan perhitungan tersebut dapat diketahui bahwa ada 5 item pertanyaan yang tidak valid ( $r$ hitung $<0,239$ ). Dalam tahap selanjutnya item yang tidak valid tersebut tidak diikutsertakan.

Setelah data terkumpul, dilakukan proses pengolahan data dan dibuat tabulasi. Analisis disajikan dalam bentuk univariat dan bivariat. Uji satistik menggunakan uji chi-square $\left(\chi^{2}\right)$ dan uji $t$-test dengan interval kepercayaan (IK) 95\%. Penelitian dilaksanakan setelah mendapatkan ijin surat kelayakan etik dari Komite Etik Biomedis pada Manusia Fakultas Kedokteran Universitas Gadjah Mada dengan nomor KE/FK/242/EC tahun 2010.

\section{HASIL}

\section{Karakteristik subjek penelitian}

Karakteristik umum subjek disajikan pada Tabel 1. Rata-rata subjek berusia 10,31 tahun dan berjenis kelamin laki- laki sebanyak $51,8 \%$ dan perempuan $48,2 \%$. Sekitar $25,9 \%$ subjek mengalami stunted (pendek), dan 6,5\% kurus. Subjek memiliki IQ di bawah rata-rata $(I Q<90)$ sebanyak $35,1 \%$.

Sebanyak $32,71 \%$ subjek dengan status gizi pendek memiliki kemampuan kognitif di bawah ratarata. Persentase ini lebih tinggi dibandingkan dengan subjek yang memiliki kemampuan kognitif di atas rata-rata yaitu sebesar $22,22 \%$. Berdasarkan status gizi IMT/U, sebagian besar subjek memiliki status gizi normal. Persentase subjek yang termasuk kategori kurus, overweight, dan obese pada kelompok dengan kemampuan kognitif di atas rata-rata berturut-turut sebesar $4,9 \%, 5,2 \%$, dan $2,6 \%$.

Subjek dengan motivasi rendah memiliki persentase lebih tinggi pada kelompok subjek dengan kemampuan kognitif di bawah rata-rata $(14,95 \%)$ bila dibandingkan dengan kelompok yang memiliki kemampuan kognitif di atas rata-rata $(5,05 \%)$.

Sebagian besar subjek memiliki jam belajar antara 1-2 jam, dengan persentase sebesar $83,18 \%$ pada kelompok subjek dengan kemampuan kognitif di bawah rata-rata dan $76,26 \%$ pada kelompok subjek dengan kemampuan kognitif di atas rata-rata. Distribusi subjek dengan jam belajar lebih dari 2 jam lebih tinggi
Tabel 1. Gambaran umum subjek di Kecamatan Cangkringan Daerah Istimewa Yogyakarta Tahun 2010

\begin{tabular}{|c|c|c|c|}
\hline Variabel & $\mathbf{n}$ & $\%$ & Mean (土SD) \\
\hline \multicolumn{4}{|l|}{ Jenis kelamin } \\
\hline Laki- laki & 158 & 51,8 & \\
\hline Perempuan & 147 & 48,2 & \\
\hline Umur & & & $\begin{array}{c}\text { 10,31 tahun } \\
( \pm 11,37 \text { tahun })^{*}\end{array}$ \\
\hline \multicolumn{4}{|l|}{ Inteligence Quotient } \\
\hline $\begin{array}{l}\text { Di bawah rata-rata (IQ } \\
<90)\end{array}$ & 107 & 35,1 & \\
\hline $\begin{array}{l}\text { Di atas rata-rata (IQ } \\
\geq 90)\end{array}$ & 198 & 64,9 & $95,8( \pm 16,11)$ \\
\hline
\end{tabular}

\begin{tabular}{|c|c|c|c|}
\hline Status Gizi & & & \\
\hline TB/U & & & \\
\hline Pendek & 79 & 25,9 & \\
\hline Normal & 226 & 74,1 & \\
\hline IMT/U & & & \\
\hline Kurus & 20 & 6,5 & \\
\hline Normal & 257 & 84,3 & \\
\hline Overweight & 18 & 5,9 & \\
\hline Obesity & 10 & 3,3 & \\
\hline Motivasi belajar & & & \\
\hline Rendah & 26 & 8,5 & \\
\hline Tinggi & 279 & 91,5 & \\
\hline Prestasi belajar & & & \\
\hline Kurang & 145 & 47,5 & \\
\hline Baik & 160 & 52,5 & \\
\hline Bahasa Indonesia & & & $68,65( \pm 11,31)$ \\
\hline Matematika & & & $60,35( \pm 12,53)$ \\
\hline
\end{tabular}

* Median ( \pm SD)

pada kelompok dengan kemampuan kognitif di atas rata-rata, yaitu sebesar $22,73 \%$.

Pelajaran Bahasa Indonesia adalah mata pelajaran yang paling disukai, baik oleh kelompok subjek yang memiliki kemampuan kognitif di bawah rata-rata dan kelompok dengan kemampuan kognitif di atas rata-rata, dengan persentase sebesar 31,78\% dan $31,31 \%$. Selain mata pelajaran Bahasa Indonesia, IPA merupakan mata pelajaran yang paling disukai pada kelompok dengan kemampuan kognitif di bawah rata-rata yaitu sebesar $35,51 \%$. Mata pelajaran matematika hanya disukai oleh $19,19 \%$ subjek dengan kemampuan kognitif di atas rata-rata.

Sebagian besar subjek memiliki kemampuan kognitif di atas rata-rata dan prestasi belajar Bahasa Indonesia yang baik, yaitu sebanyak $42,3 \%$, sedangkan subjek dengan kemampuan kognitif di bawah rata-rata, sebagian besar memiliki prestasi Bahasa Indonesia yang kurang (23,9\%). 
Sebagian besar subjek dengan kemampuan kognitif di atas rata-rata memiliki prestasi belajar matematika yang baik $(36,7 \%)$, sedangkan subjek dengan kemampuan kognitif di bawah rata-rata sebagian besar memiliki prestasi belajar matematika kurang $(23,6 \%)$. Subjek yang memiliki prestasi belajar Bahasa Indonesia kurang $(46,6 \%)$ hampir sama jumlahnya dengan persentase subjek yang memiliki prestasi belajar Bahasa Indonesia baik (53.4\%). Persentase subjek yang memiliki prestasi belajar matematika kurang $(51,8 \%)$ lebih besar dibandingkan dengan persentase subjek dengan prestasi belajar matematika baik $(48,2 \%)$.

\section{Hubungan status gizi (TB/U) dengan kemampuan kognitif}

Hasil uji statistik menunjukkan ada hubungan yang signifikan antara status gizi berdasarkan $T B / U$ dengan kemampuan kognitif anak SD $(p<0,05)$. Berdasarkan hasil analisis diperoleh OR 1,70 yang berarti anak dengan status gizi pendek mempunyai risiko 1,70 kali memiliki kemampuan kognitif di bawah rata-rata dibandingkan dengan anak yang memiliki status gizi normal (Tabel 2).

Rata-rata status gizi subjek yang memiliki kemampuan kognitif di bawah rata-rata $(-1,55 \pm 0,93)$ secara signifikan lebih rendah daripada subjek yang memiliki kemampuan kognitif di atas ratarata $(-1,26 \pm 1,03)(p<0,05)$. Hal ini menunjukkan bahwa status gizi yang tidak baik, terutama status gizi menurut $\mathrm{TB} / \mathrm{U}$, masih berhubungan dengan rendahnya kemampuan kognitif pada anak usia sekolah dasar.

\section{Hubungan status gizi (IMT/U) dengan kemampuan kognitif}

Hubungan status gizi (IMT/U) dengan kemampuan kognitif disajikan pada Tabel 2. Tidak terdapat hubungan yang signifikan antara IMT/U dengan kemampuan kognitif pada anak $S D$ di Kecamatan Cangkringan ( $p>0,05)$. Namun demikian, hasil uji beda yang disajikan pada Tabel 3, menunjukkan tidak terdapat perbedaan rata-rata status gizi (IMT/U) yang signifikan antara subjek yang memiliki kemampuan kognitif di bawah ratarata dan di atas rata-rata $(p>0,05)$

\section{Hubungan status gizi (TB/U) dengan prestasi belajar}

Tidak terdapat hubungan yang signifikan antara status gizi subjek dengan prestasi belajar Bahasa Indonesia maupun matematika ( $p=0,17$ untuk Bahasa Indonesia dan $\mathrm{p}=0,64$ untuk matematika) (Tabel 2). Hasil uji beda antara prestasi belajar Bahasa Indonesia dan matematika menurut status gizi (TB/U) pada subjek penelitian menunjukkan ada perbedaan rata-rata prestasi belajar Bahasa Indonesia $(p=0,01$, $p<0,05)$ dan matematika $(p=0,03, p<0,05)$ yang signifikan antara subjek yang memiliki status gizi pendek dan normal, dengan beda 3,87 poin untuk

Tabel 2. Hubungan status gizi (TB/U dan IMT/U) dan motivasi belajar dengan kemampuan kognitif

\begin{tabular}{|c|c|c|c|c|c|c|c|}
\hline \multirow{3}{*}{ Variabel } & \multicolumn{4}{|c|}{ Kemampuan kognitif } & \multirow{3}{*}{ OR } & \multirow{3}{*}{$95 \% \mathrm{Cl}$} & \multirow{3}{*}{$\mathbf{p}$} \\
\hline & \multicolumn{2}{|c|}{$<$ Rata-rata } & \multicolumn{2}{|c|}{$\geq$ Rata-rata } & & & \\
\hline & $\mathbf{n}$ & $\%$ & $\mathbf{n}$ & $\%$ & & & \\
\hline \multicolumn{8}{|l|}{ Status gizi (TB/U) } \\
\hline Pendek & 35 & 11,5 & 44 & 14,4 & 1,70 & $1,01-2,88$ & $0,046^{*}$ \\
\hline Normal & 72 & 23,6 & 154 & 50,5 & & & \\
\hline \multicolumn{8}{|l|}{ Status gizi (IMT/U) } \\
\hline Kurus & 5 & 1,6 & 15 & 4,9 & & & 0,06 \\
\hline Normal & 98 & 32,1 & 159 & 52,1 & & & \\
\hline Overweight & 2 & 0,7 & 16 & 5,2 & & & \\
\hline Obesity & 2 & 0,7 & 8 & 2,6 & & & \\
\hline \multicolumn{8}{|l|}{ Motivasi belajar } \\
\hline Rendah & 16 & 5,2 & 10 & 3,3 & 3,31 & $1,44-7,57$ & $0,003^{*}$ \\
\hline Tinggi & 91 & 29,8 & 188 & 61,6 & & & \\
\hline
\end{tabular}

* Signifikan $(p<0,05)$ 
prestasi belajar Bahasa Indonesia dan 3,52 poin untuk prestasi belajar matematika (Tabel 4).

\section{Hubungan motivasi belajar dengan kemampuan kognitif}

Terdapat hubungan yang signifikan antara motivasi belajar dengan kemampuan kognitif anak $(p<0,005)$ (Tabel 2). Kemudian berdasarkan hasil analisis diperoleh $\mathrm{OR}=3,31$ yang artinya anak yang memiliki motivasi rendah mempunyai risiko 3,3 kali memiliki kemampuan kognitif di bawah rata-rata. Hasil uji beda (Tabel 3), menunjukkan rata-rata motivasi belajar subjek yang memiliki kemampuan kognitif di bawah rata-rata $(75,79 \pm 8,93)$ secara signifikan lebih rendah daripada subjek yang memiliki kemampuan kognitif di atas rata-rata $(80,93 \pm 9,79)(p<0,05)$. Dengan demikian, motivasi belajar yang rendah masih berhubungan dengan rendahnya kemampuan kognitif pada anak usia sekolah dasar.

\section{Hubungan motivasi belajar dengan prestasi belajar}

Pada Tabel 5 dan 6, dapat dilihat adanya hubungan yang signifikan antara motivasi belajar dengan prestasi Bahasa Indonesia $(p>0,05)$, namun tidak terdapat hubungan yang signifikan antara motivasi belajar dengan prestasi belajar Matematika $(p>0,05)$

\section{Hubungan kemampuan kognitif dengan prestasi belajar}

Terdapat hubungan yang signifikan antara prestasi belajar Bahasa Indonesia dengan kemampuan kognitif anak $(p<0,05)$. Dari hasil analisis juga diperoleh $\mathrm{OR}=4,01$, artinya anak dengan kemampuan kognitif di bawah rata-rata mempunyai risiko 4,01 kali memiliki prestasi belajar Bahasa Indonesia yang kurang. Demikian pula terdapat hubungan yang signifikan antara prestasi belajar matematika dengan kemampuan kognitif anak $(p<0,05)$. Dengan $\mathrm{OR}=2,68$, artinya anak dengan kemampuan kognitif di bawah rata-rata mempunyai risiko 2,68 kali memiliki prestasi belajar matematika yang kurang. Hubungan kemampuan kognitif dengan prestasi belajar Bahasa Indonesia maupun matematika ini disajikan pada Tabel 5 dan 6.

Hasil uji beda (Tabel 3) didapatkan, ratarata prestasi belajar Bahasa Indonesia subjek yang memiliki kemampuan kognitif di bawah rata-rata $(63,30 \pm 11,59)$ secara signifikan lebih rendah daripada subjek yang memiliki kemampuan kognitif di atas rata-rata $(71,55 \pm 10,05)$ dengan beda 8,25 poin $(p<0,05)$. Demikian pula dengan

Tabel 3. Hasil uji beda status gizi (TB/U dan IMT/U), motivasi belajar, dan prestasi belajar menurut kemampuan kognitif

\begin{tabular}{|c|c|c|c|c|}
\hline \multirow{3}{*}{ Variabel } & \multicolumn{2}{|c|}{ Kemampuan Kognitif } & \multirow{3}{*}{$\mathbf{T}$} & \multirow{3}{*}{$\mathbf{p}$} \\
\hline & $<$ rata-rata & $\geq$ rata-rata & & \\
\hline & Mean \pm SD & Mean \pm SD & & \\
\hline Status gizi (TB/U) & $-1,55 \pm 0,93$ & $-1,26 \pm 1,03$ & 2,37 & $0,018^{*}$ \\
\hline Status gizi (IMT/U) & $-0,55 \pm 0,98$ & $-0,51 \pm 1,31$ & 0,23 & 0,80 \\
\hline Motivasi belajar & $75,79 \pm 8,93$ & $80,93 \pm 9,79$ & 4,52 & $0,00^{*}$ \\
\hline Prestasi belajar (Bahasa Indonesia) & $63,30 \pm 11,59$ & $71,55 \pm 10,05$ & 6,48 & $0,00^{*}$ \\
\hline Prestasi belajar (Matematika) & $54,89 \pm 11,85$ & $63,30 \pm 11,91$ & 5,89 & $0,00^{*}$ \\
\hline
\end{tabular}

* Signifikan $(p<0,05)$

Tabel 4. Hasil uji beda prestasi belajar Bahasa Indonesia dan matematika menurut status gizi (TB/U)

\begin{tabular}{lccccc}
\hline \multirow{2}{*}{\multicolumn{1}{c}{ Variabel }} & \multicolumn{2}{c}{ Status gizi (TB/U) } & & \multirow{2}{*}{ T } & p \\
\cline { 2 - 3 } & Pendek & Normal & & \\
\cline { 2 - 3 } & Mean \pm SD & Mean \pm SD & & \\
\hline Prestasi belajar Bahasa Indonesia & $65,79 \pm 11,31$ & $69,66 \pm 11,16$ & & 2,64 & 0,01 \\
Prestasi belajar matematika & $57,74 \pm 12,55$ & $61,26 \pm 12,42$ & 2,16 & 0,03 \\
\hline
\end{tabular}


Tabel 5. Hubungan status gizi (TB/U), motivasi belajar, kemampuan kognitif dengan prestasi belajar Bahasa Indonesia

\begin{tabular}{|c|c|c|c|c|c|c|c|}
\hline \multirow{3}{*}{ Variabel } & \multicolumn{4}{|c|}{ Prestasi belajar } & \multirow{3}{*}{ OR } & \multirow{3}{*}{$95 \% \mathrm{Cl}$} & \multirow{3}{*}{$\mathbf{p}$} \\
\hline & \multicolumn{2}{|c|}{ Kurang } & \multicolumn{2}{|c|}{ Baik } & & & \\
\hline & $\mathbf{n}$ & $\%$ & $\mathbf{n}$ & $\%$ & & & \\
\hline \multicolumn{8}{|c|}{ Status gizi (TB/U) } \\
\hline Pendek & 42 & 13,8 & 37 & 12,1 & 1,43 & $0,86-2,39$ & 0,17 \\
\hline Normal & 100 & $32 ., 8$ & 126 & 41,3 & & & \\
\hline \multicolumn{8}{|l|}{ Motivasi belajar } \\
\hline Rendah & 19 & 12,1 & 7 & 2,3 & 3,44 & $1,40-8,45$ & $0,01^{*}$ \\
\hline Tinggi & 123 & 40,3 & 156 & 51,1 & & & \\
\hline \multicolumn{8}{|c|}{ Kemampuan kognitif } \\
\hline$<$ Rata-rata & 73 & 23,9 & 34 & 11,1 & 4,01 & $2,43-6,62$ & $0,00^{*}$ \\
\hline$\geq$ Rata-rata & 69 & 22,6 & 129 & 42,3 & & & \\
\hline
\end{tabular}

* Signifikan $(p<0,05)$

Tabel 6. Hubungan status gizi (TB/U), motivasi belajar, kemampuan kognitif dengan prestasi belajar matematika

\begin{tabular}{|c|c|c|c|c|c|c|c|}
\hline \multirow{3}{*}{ Variabel } & \multicolumn{4}{|c|}{ Prestasi belajar } & \multirow{3}{*}{ OR } & \multirow{3}{*}{$95 \% \mathrm{Cl}$} & \multirow{3}{*}{$\mathbf{p}$} \\
\hline & \multicolumn{2}{|c|}{ Kurang } & \multicolumn{2}{|c|}{ Baik } & & & \\
\hline & $\mathbf{n}$ & $\%$ & $n$ & $\%$ & & & \\
\hline \multicolumn{8}{|c|}{ Status gizi (TB/U) } \\
\hline Pendek & 48 & 15,7 & 31 & 10,2 & 1,63 & $0,97-2,75$ & 0,64 \\
\hline Normal & 110 & 36,1 & 116 & 38,0 & & & \\
\hline \multicolumn{8}{|l|}{ Motivasi belajar } \\
\hline Rendah & 12 & 3,9 & 14 & 4,6 & 0,78 & $0,35-1,75$ & 0,55 \\
\hline Tinggi & 146 & 47,9 & 133 & 43,6 & & & \\
\hline \multicolumn{8}{|c|}{ Kemampuan kognitif } \\
\hline$<$ Rata-rata & 72 & 23,6 & 35 & 11,5 & 2,68 & $1,64-4,38$ & $0,00^{*}$ \\
\hline$\geq$ Rata-rata & 86 & 28,2 & 112 & 36,7 & & & \\
\hline
\end{tabular}

* Signifikan $(p<0,05)$

rata-rata prestasi belajar matematika subjek yang memiliki kemampuan kognitif di bawah rata-rata $(54,89 \pm 11,85)$ secara signifikan lebih rendah daripada subjek yang memiliki kemampuan kognitif di atas rata-rata $(63,30 \pm 11,91)$, dengan beda 8,41 poin $(p<0,05)$. Hal ini menunjukkan bahwa rendahnya prestasi belajar masih berhubungan dengan kemampuan kognitif pada anak usia sekolah dasar.

\section{BAHASAN}

\section{Status gizi dan kemampuan kognitif}

Hasil penelitian menunjukkan bahwa subjek dengan status gizi pendek yang memiliki kemampuan kognitif di bawah rata-rata persentasenya lebih tinggi
$(32,71 \%)$ bila dibandingkan dengan subjek dengan status gizi pendek yang memiliki kemampuan kognitif di atas rata-rata $(22,22 \%)$. Sedangkan untuk status gizi menurut IMT/U, sebagian besar subjek memiliki status gizi normal $(84,3 \%)$, sedangkan subjek dengan status gizi kurus hanya sekitar $1,6 \%$ pada kelompok subjek dengan kemampuan kognitif di bawah rata-rata. Hal ini lebih rendah persentasenya bila dibandingkan dengan subjek pada kelompok dengan kemampuan kognitif di atas rata-rata sebesar $4,9 \%$

Terdapat hubungan yang signifikan antara status gizi berdasarkan TB/U dengan kemampuan kognitif subjek, dengan $p=0,046(p<0,05)$, sedangkan untuk status gizi menurut IMT/U dengan kemampuan kognitif pada anak SD di Kecamatan Cangkringan 
tidak terdapat hubungan yang signifikan $(p=0,058$, $p>0,05$ ).

Hasil penelitian ini sejalan dengan penelitian di Costa Rica tahun 1992 menemukan adanya hubungan antara status gizi menurut TB/U dengan perkembangan kognitif (21). Status gizi pendek adalah sebuah keadaan yang dapat mempengaruhi pertumbuhan anak pada tahap yang sangat dini hingga usia 3 atau 4 tahun (22). Status gizi pendek juga mengindikasikan lambatnya pertumbuhan tulang yang membutuhkan waktu lama untuk menimbulkan efek berarti/ pulih kembali (21). Keadaan gizi kurang dapat mengakibatkan perubahan struktural dan fungsional pada otak. Anak-anak yang pendek memiliki lingkar kepala lebih kecil. Lingkar kepala dapat memprediksikan nilai IQ pada usia kanak-kanak selanjutnya (23). Pertumbuhan dan perkembangan sel-sel otak anak memerlukan zat gizi yang adekuat. Kecukupan zat gizi pada saat ini akan sangat mempengaruhi tumbuh kembang anak pada periode selanjutnya (4).

Dari penelitian ini, didapatkan prevalensi status gizi pendek sebesar $25,9 \%$ dari seluruh subjek penelitian. Status gizi pendek bila skor-z $<-2$ SD dan indikator prevalensi status gizi pendek dikatakan rendah bila prevalensi $<20 \%$ (24). Prevalensi status gizi pendek di Kecamatan Cangkringan tergolong dalam kategori medium.

Hasil penelitian ini menemukan bahwa anak dengan status gizi pendek mempunyai risiko 1,7 kali memiliki kemampuan kognitif di bawah ratarata dibandingkan dengan anak yang memiliki status gizi normal (tidak pendek). Bila dilihat dari rata-rata z-score pada kelompok kemampuan kognitif di atas rata-rata $(-1,26 \pm 1,03)$ maupun kelompok kemampuan kognitif di bawah rata-rata $(-1,55 \pm 0,93)$, masih tergolong dalam kategori normal ( $z$-score $>-2)$. Dari rerata tersebut, dapat disimpulkan bahwa pada daerah endemik GAKY seperti Kecamatan Cangkringan, anak sekolah dasar dengan kemampuan kognitif di atas rata-rata memiliki status gizi (TB/U) yang lebih baik daripada yang memiliki kemampuan kognitif di bawah ratarata.

Median IQ subjek pada penelitian ini adalah 98. Median IQ subjek tergolong dalam kategori rata- rata anak normal dengan rentang IQ sebesar 90109. Dari hasil skrining terhadap 6 SD di Kecamatan Cangkringan yang menjadi subjek penelitian, terdapat $35,1 \%$ anak memiliki kemampuan kognitif di bawah rata-rata. Median IQ pada kelompok anak dengan kemampuan kognitif di bawah rata-rata adalah 80. Median IQ ini jauh di bawah kategori rata-rata anak normal. Sebuah penelitian di daerah endemik GAKY berat di Kabupaten Malang tahun 1998 menemukan bahwa anak- anak sekolah dasar dengan gangguan bicara, menulis, dan berhitung memiliki IQ di bawah 80 dan berusia di atas 8 tahun. Anak- anak yang memiliki salah satu saja dari gangguan ini dapat diidentifikasikan sebagai penderita kretin ringan (13).

Kekurangan gizi pada masa dini perkembangan anak akan menghentikan sintesis protein dan DNA, akibatnya adalah berkurangnya pertumbuhan otak, sehingga lebih sedikit sel- sel otak yang berukuran normal. Dan dampaknya baru akan terlihat pada struktur dan fungsi otak pada masa kehidupan mendatang, sehingga berpengaruh pada kecerdasan anak. Bukan hanya kekurangan energi dan protein saja yang akan berpengaruh pada kerusakan struktur saraf- saraf pusat dan pertumbuhan otak. Ada berbagai defisiensi lain yang juga berpengaruh pada janin, yaitu defisiensi $\mathrm{Fe}$, asam folat, vitamin $\mathrm{B} 12$, yodium, seng, vitamin A, thiamin, dan kalsium (3).

\section{Status gizi (TB/U) dan prestasi belajar}

Sebanyak 100 (32,8\%) subjek dengan status gizi normal dan memiliki prestasi belajar Bahasa Indonesia yang kurang. Hal ini tidak berbeda jauh dengan jumlah subjek yang memiliki status gizi normal dengan prestasi Bahasa Indonesia yang baik sebanyak 126 (41,3\%). Demikian juga terjadi pada hubungan status gizi dengan prestasi belajar matematika. Sebanyak 116 (38,0\%) subjek memiliki status gizi normal dan prestasi belajar matematika yang baik. Tidak berbeda jauh dengan jumlah anak yang memiliki status gizi normal tetapi memiliki prestasi belajar matematika yang kurang yaitu sebanyak $110(36,1 \%)$ subjek.

Pada dasarnya, anak-anak yang berada di daerah endemik memiliki kondisi yang tidak normal 
bila dibandingkan dengan anak-anak yang berada di daerah non- endemik. Defisiensi yodium yang terus-menerus menyebabkan status gizi, kemampuan kognitif, maupun prestasi belajar yang lebih rendah dibandingkan anak-anak yang berada di daerah non-endemik. Anak-anak yang berada di daerah endemik akan sama-sama mengalami keterlambatan pertumbuhan dan kematangan tulang dibandingkan dengan anak-anak di daerah non-endemik (25). Sebuah penelitian metaanalisis dan penelitian di Kabupaten Malang tahun 1998 menyebutkan bahwa anak-anak daerah endemik GAKY selain memiliki IQ lebih rendah juga memiliki gangguan bicara, menulis, dan berhitung $(13,26)$. Dalam penelitian ini, hal tersebut terlihat dari masih banyaknya jumlah subjek yang memiliki prestasi belajar Bahasa Indonesia dan matematika yang kurang.

Hasil uji chi-square pada penelitian ini menunjukkan tidak terdapat hubungan yang signifikan antara status gizi (TB/U) dengan prestasi belajar, baik Bahasa Indonesia maupun matematika. Status gizi bukan satu-satunya faktor yang mempengaruhi prestasi belajar. Penyesuaian diri secara pribadi dan sosial juga merupakan faktor penentu keberhasilan dan kegagalan anak di sekolah (27). Ketertarikan siswa terhadap suatu pelajaran, jumlah tugas yang dapat dikerjakan, tujuan tugas yang diberikan, kepribadian, konsep diri siswa, kecemasan, fasilitas belajar, peralatan materi pembelajaran, rasio jumlah murid dan guru merupakan faktor lain yang menunjang prestasi anak di sekolah (15).

\section{Motivasi belajar dan kemampuan kognitif}

Sebanyak $5,2 \%$ anak dengan motivasi belajar rendah memiliki kemampuan kognitif di bawah rata-rata, dan hanya 3,3\% anak dengan motivasi rendah yang memiliki kemampuan kognitif di atas rata-rata. Namun demikian, sebagian besar subjek sudah memiliki motivasi belajar yang tinggi $(91,5 \%)$. Berdasarkan analisis chi-square didapatkan nilai p sebesar 0,03 $(p<0,05)$ dan dapat disimpulkan adanya hubungan yang signifikan antara motivasi belajar dengan kemampuan kognitif anak.

Berdasarkan hasil penelitian ini juga diperoleh anak yang memiliki motivasi rendah mempunyai risiko 3,3 kali memiliki kemampuan kognitif di bawah rata-rata. Dengan demikian, anak dengan motivasi belajar yang tinggi memiliki kemampuan kognitif yang lebih baik dibandingkan dengan anak yang memiliki motivasi belajar rendah. Hal ini sejalan dengan sebuah penelitian yang menyatakan bahwa motivasi berhubungan positif dengan kemampuan intelektual dan persepsi kompetensi serta berbanding terbalik dengan kecemasan akademis. Siswa dengan motivasi intrinsik akademik yang lebih tinggi cenderung memiliki kemampuan intelektual secara signifikan lebih tinggi, memiliki persepsi yang baik terhadap kemampuan akademik mereka, dan rasa kecemasan akademis yang lebih rendah. Hal ini juga dirasakan secara signifikan oleh para guru mereka sehingga lebih termotivasi untuk mengajar (16).

\section{Motivasi belajar dan prestasi belajar}

Hasil penelitian ini menunjukkan sebagian besar subjek di SD Kecamatan Cangkringan memiliki motivasi belajar yang tinggi $(91,5 \%)$. Sebanyak 123 (40,3\%) subjek yang memiliki motivasi tinggi, tetapi memiliki prestasi Bahasa Indonesia yang kurang. Ada 146 (47,9\%) subjek yang memiliki motivasi belajar yang tinggi, namun memiliki prestasi matematika yang kurang.

Penelitian di India (14) menemukan bahwa anak-anak yang berada di daerah defisiensi yodium berat (severe iodine-deficient) merupakan anakanak lambat dalam belajar dibandingkan dengan anak-anak yang berada di daerah defisiensi yodium sedang (moderate iodine-deficient). Anak-anak pada daerah defisiensi berat ternyata juga memiliki skor motivasi belajar yang lebih rendah. Nilai stimulasi sosio-psikologi yang rendah menurunkan motivasi berprestasi yang rendah pula. Hal ini disebabkan defisiensi yodium secara signifikan menghambat pembentukan dan konsolidasi respon stimulus pada susunan saraf pusat di otak bagian korteks. Kelambatan belajar pada subjek yang berada di daerah defisiensi yodium berat bukan sepenuhnya disebabkan oleh gangguan neurologis, namun juga hasil dari kurangnya rangsangan psikologis di daerah endemis yang diperlukan untuk pengembangan psikologis normal $(28,29)$. 
Di daerah endemik yodium, stimulasi psikologis akan melemah disebabkan oleh kelompok sosial di sekitar anak-anak ini membosankan, apatis, dan tidak termotivasi. Akibatnya, anak-anak dengan kekurangan yodium tidak menemukan lingkungan sosio-psikologi yang menyenangkan untuk belajar, mendapatkan keterampilan baru, dan berbagai kemampuan kognitif lainnya (29).

Hasil uji chi-square menunjukkan bahwa terdapat hubungan yang signifikan antara motivasi belajar dengan prestasi belajar Bahasa Indonesia, tetapi tidak terdapat hubungan yang signifikan antara motivasi belajar dengan prestasi belajar matematika. Prestasi belajar anak dapat ditunjang oleh beberapa faktor, salah satunya ketertarikan siswa terhadap suatu mata pelajaran (15). Dari hasil penelitian ini juga ditemukan bahwa sebagian besar subjek menyukai mata pelajaran Bahasa Indonesia $(31,48 \%)$ dibandingkan matematika (18\%). Hal ini merupakan salah satu faktor yang menyebabkan terdapat hubungan yang signifikan antara motivasi belajar dengan prestasi Bahasa Indonesia subjek, tetapi tidak dengan matematika.

\section{Kemampuan kognitif dan prestasi belajar}

Penelitian ini menemukan persentase subjek dengan kemampuan kognitif di atas rata-rata dengan prestasi belajar Bahasa Indonesia yang baik lebih tinggi $(42,3 \%)$ dibandingkan dengan subjek yang memiliki kemampuan kognitif di bawah ratarata dengan prestasi belajar Bahasa Indonesia yang baik $(11,1 \%)$. Hasil penelitian ini sejalan dengan penelitian di daerah GAKY Kabupaten Malang tahun 1998 yang melakukan penelitian mengenai kemampuan bicara, menulis, dan berhitung pada anak SD yaitu bahwa anak yang mengalami gangguan bicara, menulis, dan berhitung memiliki IQ di bawah 80 (13).

Hasil analisis untuk kemampuan kognitif dan prestasi belajar Bahasa Indonesia dapat disimpulkan bahwa anak dengan kemampuan kognitif di bawah rata-rata mempunyai risiko 4,01 kali memiliki prestasi belajar Bahasa Indonesia yang kurang. Secara keseluruhan, sebagian besar subjek memiliki prestasi belajar matematika yang kurang $(51,8 \%)$ dengan persentase terbesar
$(28,2 \%)$ terdapat pada kelompok subjek dengan kemampuan kognitif di atas rata-rata.

Berdasarkan analisis chi-square didapatkan, nilai $p=0,00$ sehingga dapat disimpulkan bahwa ada hubungan yang signifikan antara prestasi belajar matematika dengan kemampuan kognitif anak. Nilai $O R=2,68$, yang berarti anak dengan kemampuan kognitif di bawah rata-rata mempunyai risiko 2,68 kali memiliki prestasi belajar Matematika yang kurang.

Nilai Bahasa Indonesia mencerminkan kemampuan verbal, sedangkan nilai matematika mencerminkan kemampuan berhitung subjek. Penelitian ini sejalan dengan penelitian di daerah GAKY Kabupaten Malang tahun 1998 mengenai kemampuan bicara, menulis, dan berhitung pada anak SD, yaitu bahwa anak yang mengalami gangguan bicara, menulis, dan berhitung memiliki IQ di bawah 80 (13). Perkembangan kognitif anak usia sekolah dasar menentukan inteligensi anak tersebut. Hal ini disebabkan inteligensi telah dianggap sebagai suatu norma yang menentukan perkembangan kemampuan dan pencapaian optimal hasil belajar anak di sekolah. Dengan mengetahui inteligensinya, seorang anak dapat dikategorikan sebagai anak yang pandai/ cerdas (genius), sedang, atau bodoh (idiot). Inteligensi dapat dibagi menjadi sejumlah kemampuan primer, yaitu: pemahaman verbal (verbal comprehension), kefasihan menggunakan kata-kata (word fluency), kemampuan bilangan (numerical ability), kemampuan ruang (spatial faktor), kemampuan mengingat (memory), kecepatan pengamatan (perceptual speed), dan kemampuan penalaran (reasoning) (30).

\section{KESIMPULAN DAN SARAN}

Berdasarkan hasil penelitian yang sudah dilakukan dapat disimpulkan bahwa status gizi berdasarkan TB/U merupakan faktor risiko terhadap kemampuan kognitif anak SD yang tinggal di daerah endemik GAKY. Anak dengan status gizi pendek berisiko 1,7 kali memiliki kemampuan kognitif di bawah rata-rata dibandingkan dengan anak yang memiliki status gizi berdasarkan TB/U normal. Tidak ada hubungan yang signifikan antara 
status gizi menurut IMT/U dengan kemampuan kognitif pada anak SD di Kecamatan Cangkringan. Motivasi belajar merupakan faktor risiko terhadap kemampuan kognitif anak SD yang tinggal di daerah endemik GAKY. Anak dengan motivasi rendah berisiko 3,3 kali memiliki kemampuan kognitif di bawah rata-rata.

Melihat tingginya prevalensi status gizi pendek sebesar $25,9 \%$, serta masih adanya anak SD dengan IQ dan prestasi belajar yang rendah di Kecamatan Cangkringan, perlu dukungan melalui program suplementasi yodium yang telah dilakukan oleh Pemerintah. Tidak hanya yodium, suplementasi mikronutien seperti zat besi ( $\mathrm{Fe})$, zink, dan vitamin B12 juga terbukti penting terhadap perkembangan kognitif anak sejak masa prakonsepsi, ibu hamil, dan menyusui. Selain itu, pada penelitian ini belum dikaji status gizi dari segi asupan maupun pola makan subjek. Kecukupan zat-zat gizi seperti zat besi $(\mathrm{Fe})$, yodium, zink, dan vitamin B12 berhubungan dengan perkembangan kognitif anak, maka pengenalan 'home fortification programme' seperti sprinkle dianjurkan untuk dilakukan. Selain itu, perlu adanya perubahan perilaku melalui peningkatan pengetahuan, praktek gizi, dan kesehatan yang baik. Melakukan program diversifikasi pangan melalui capacity dan technical building produksi pangan maupun pendampingan terhadap keluarga, mulai dari hidup bersih dan pemanfaatan tanaman perkarangan dan kebun sekolah untuk program makanan tambahan anak sekolah (PMT-AS) agar akses pangan terhadap kelompok rawan lebih mudah. Untuk penelitian yang akan datang diharapkan dapat melihat perkembangan anak terutama kognitif dari sudut perspektif yang lain, seperti status gizi dari segi asupan mikronutrien maupun pola makan anak.

\section{RUJUKAN}

1. Sediaoetama A. IImu gizi jilid II. Jakarta: Dian Rakyat; 2009.

2. Walker S, Wachs T, Gardner J, Lozoff B, Wasserman G, Pollitt E, et al. Child development: risk factor for adverse outcomes in developing countries. Lancet. 2007;369(9556):145-7.
3. Soetjiningsih. Tumbuh kembang anak. Jakarta: EGC; 1995.

4. Sediaoetama A. IImu gizi jilid I. Jakarta: Dian Rakyat; 2008.

5. Badan Perencanaan Pembangunan Nasional. Rencana aksi nasional pangan dan gizi 2006-2010. Jakarta: Badan Perencanaan Pembangunan Nasional; 2007.

6. Freeman $\mathrm{H}$, Klein R, Townsend J, Lechtig A. Nutrition and cognitive development among rural Guatemalan children. Am J Public Heal. 1980;70:1277-85.

7. Black M. Micronutrient deficiencies and cognitive functioning. J Nutr. 2003;133(11):3927-31.

8. Howson C, Kennedy E, Horwitz A. Key elements in the design and implementation of micronutrient interventions in: prevention of micronutrient deficiencies: tools for policymakers and public health workers. Washington DC: National Academy Press; 1998.

9. Winiewski S. Linking early childhood nutrition and health problems to school achievement: a cross-section analysis of grade 4 students in Sri Lanka. Denver Colorado; 2004.

10. World Health Organization. Assesment of iodine deficiency disorders and monitoring their elimination: a guide for programme managers 3rd ed. New York: WHO; 2007.

11. West C, Jooste P, Pandav C. Iodium dan gangguan akibat kekurangan iodium. Gizi kesehatan masyarakat. Jakarta: EGC; 2009.

12. Gregory R. Psychological testing: history, principles, and applications. Boston: Allyn and Bacon; 1998.

13. Budiman B, Latinulu S, Saraswati E, Hariyadi B, Sunindya B, Sugiatwati S. Kemampuan bicara, menulis, dan berhitung untuk mengidentifikasi kretinisme pada anak sekolah dasar. Bul Penelit Kesehat. 2000;28(2).

14. Tiwari B, Godbole M, Chattopadhyay N, Mandal A, Mithal A. Learning disabilities and poor motivation to achieve due to prolonged iodine deficiency. Am J Clin Nutr. 1996;63:782-6.

15. Tella A. The impact of motivation on student's academic achievement and learning outcomes in mathematics among secondary school 
students in Nigeria. Eurasia J Math Sci Tech. 2007;3(2):149-56.

16. Gottfried A. Academic intrinsic motivation in young elementary school children. J Educ Psychol. 1990;82(3):525-38.

17. Djaali. Psikologi pendidikan. Jakarta: Bumi Aksara; 2008.

18. Ryan R, DeciE. Intrinsic and extrinsic motivations: classic definitions and new directions. Contemp Educ Psychol. 2000;25:54-67.

19. Dinas Kesehatan Sleman. Laporan pemutakhiran data GAKY (Gangguan Akibat Kekurangan Yodium) Kabupaten Sleman tahun 2003. Sleman: Pemerintah Kabupaten Sleman; 2003.

20. Departemen Kesehatan RI. Bantuan teknis untuk studi evaluasi proyek intensifikasi penanggulangan gangguan akibat kekurangan yodium (IP-GAKY). Jakarta: Departemen Kesehatan RI; 2003.

21. Laude M. Assesment of nutritional status, cognitive development, and mother- child interaction in Central American refugee children. Pan Am J Public Heal. 1999;6(3):164-70.

22. Branca F, Ferrari M. Impact of micronutrient deficiencies on growth: the stunting syndrome. Ann Nutr Metab. 2002;46:8-17.

23. Baker-Henningham H, Grantham-McGregor S. Gizi dan perkembangan anak. Gizi Kesehatan Masyarakat. Jakarta: EGC; 2009.
24. Gibson R. Principles of nutrition assesment. Oxford: Oxford University Press; 2005.

25. Koutras A, Christakis G, Trichopoulos D, DakouVoutetaki, A Kyriakopoulos, V Fontansres P, Livadas D, Gatsios D, et al. Endemic goiter in Greece: nutritional status, growth, and skeletal development of goitrous and nongoitrous populations. Am J Clin Nutr. 1973;26(12):1360-8.

26. Bleichrodt N, Garcia I, Rubio C, Escobar G, Rey $F$. A metaanalysis of research on iodine and its relationship to cognitive development. Sao Paulo: Achẻ; 1986.

27. Breckenridge M, Vincent E. Child development physical and psychological growth through adolescence. Tokyo: Toppan Company Limited; 1966.

28. Greene L. Physical growth and development, neurological maturation and behavioral functioning in two Ecuadorean Andean communities in which goiter is endemic. Am J Phys Anthr. 1973;28:119-34.

29. Benitez R, Cazar R, Stanbury J, et al. Longterm effects of correction of iodine deficiency on psychomotor and intellectual development. Pan American Health Organization. Washington DC: Pan American Health Organization; 1986. p. 182-2000.

30. Desmita. Psikologi perkembangan. Bandung: PT Remaja Rosdakarya; 2008. 


\title{
Tingkat pendapatan dan pola makan berhubungan dengan status gizi balita di Daerah Nelayan Distrik Jayapura Utara Kota Jayapura
}

\author{
Income level and diet pattern had correlation with nutritional status of underfive in fisherman area \\ of North Jayapura District Jayapura Municipality
}

Vonny Persulessy¹, Abidillah Mursyid², Agus Wijanarka²

\begin{abstract}
Background: Nutrition has an important role in human life cycle. Undernourishment in infants and underfives can cause growth and development disorder. Development of Papua community begins from village empowerment, such as nutrition improvement, health service, and people's economy. There are 544 fisherman families at District of Jayapura Utara. Main stipend of Papua community consists of rice, sago, hipere, taro and banana. Sago is consumed by the majority of people residing at coastal areas. Nutrition Status Monitoring of Jayapura Municipal Health Office in 2008 indicated that $3.4 \%$ of underfives were malnourished, $17.8 \%$ undernourished, $76 \%$ well nourished and $2.8 \%$ overnourished.

Objectives: To identify correlation between level of income and diet pattern with nutritional status of underfive in fisherman area of Jayapura District Jayapura Municipality.

Methods: The study was observational with cross sectional design. The independent variables were level of income and eating pattern; the dependent variable was nutritional status. The study was undertaken in October-December 2010 at District of North Jayapura, Jayapura Municipality involving 162 underfives (of 12-59 moths), and mothers of underfives as respondents. Data were obtained through questionnaire of income, eating pattern using food frequency questionnaire, nutritional status measured from anthropometry based on weight/age standard of WHO 2005. Data analysis used bivariate with chi square, multivariate with multiple logistic regression.

Results: There was significant correlation between income level with nutritional status with $(p=0.000)$ and between diet pattern with nutritional status $(p=0.000)$.

Conclusions: Underfives having parents with sufficient income had better nutritional status than those having parent with insufficient income. Underfives with good diet pattern had better nutritional status than those with poor diet pattern.
\end{abstract}

KEYWORDS: income, diet pattern, nutrition status of underfives, fisherman area

\begin{abstract}
ABSTRAK
Latar belakang: Secara nasional, prevalensi balita gizi buruk dan kurang menurun sebanyak 0,5\% menjadi 17,9\%. Prevalensi gizi buruk dan kurang Provinsi Papua menurut Riskesdas tahun 2010 sebanyak 16,3\%. Data neraca bahan makanan (NBM) Provinsi Papua secara kuantitas menunjukkan rata-rata peningkatan produksi bahan makanan di antaranya beras, jagung, umbi-umbian. Secara kualitas, energi dan protein melebihi angka kecukupan gizi (AKG), tetapi status gizi buruk dan kurang di Kota Jayapura mencapai $21,2 \%$ yang dipengaruhi oleh banyak faktor, yaitu tingkat pendapatan, pola makan, pengetahuan ibu, jumlah anggota dalam keluarga.

Tujuan: Untuk mengetahui hubungan antara tingkat pendapatan dan pola makan dengan status gizi balita di daerah nelayan Distrik Jayapura Utara, Kota Jayapura.
\end{abstract}

\footnotetext{
${ }^{1}$ Puskesmas Imbi, Kel. Imbi Dok VIII, Distrik Jayapura Utara, e-mail: vonnypersulessy@gmail.com

${ }^{2}$ Politeknik Kesehatan Kementerian Kesehatan Yogyakarta, JL.Tata Bumi, Yogyakarta
} 
Metode: Penelitian ini merupakan penelitian observasional dengan rancangan cross sectional. Jumlah sampel sebanyak 162 balita (usia 12-59 bulan) dan ibu balita sebagai responden. Pengumpulan data menggunakan kuesioner tingkat pendapatan, pola makan anak dalam keluarga menggunakan food frequency questionnaire (FFQ), status gizi diukur menggunakan antropometri berdasarkan BB/U standar baku WHO 2005. Analisis data bivariat menggunakan chi-square, sedangkan analisis multivariat menggunakan multiple logistic regression.

Hasil: Tingkat pendapatan dengan status gizi menunjukkan hubungan yang bermakna dengan nilai $(p=0,000)$. Pola makan dengan status gizi menunjukkan hubungan yang bemakna yaitu $(p=0,010)$. Variabel luar pengetahuan ibu dengan status gizi, jumlah anggota keluarga dengan status gizi tidak menunjukkan hubungan yang bermakna, yaitu $p>0,05$.

Kesimpulan: Terdapat hubungan yang bermakna antara tingkat pendapatan dengan status gizi, pola makan dengan status gizi. Tetapi tidak ditemukan hubungan yang bermakna antara pengetahuan ibu dengan status gizi, dan jumlah anggota keluarga dengan status gizi.

KATA KUNCI: tingkat pendapatan, pola makan, status gizi balita, daerah nelayan

\section{PENDAHULUAN}

Usia 0-24 bulan merupakan masa pertumbuhan dan perkembangan yang pesat yang sering disebut dengan periode emas sekaligus periode kritis. Pada periode ini, jika bayi dan anak balita memperoleh pola makan dan asupan gizi yang baik sesuai tumbuh kembang optimal, maka periode emas ini dapat terwujud. Sebaliknya, jika pada periode ini bayi dan anak balita tidak memperoleh asupan gizi yang cukup sesuai kebutuhannya, maka periode emas akan menjadi periode kritis yang dapat menyebabkan tumbuh kembang bayi dan anak balita akan berjalan sebagaimana mestinya. Gizi memegang peranan penting dalam siklus hidup manusia. Kekurangan gizi pada bayi dan anak balita akan mengakibatkan gangguan pertumbuhan dan perkembangan (1).

Secara nasional, prevalensi balita gizi buruk dan kurang menurun sebanyak $0,5 \%$ yaitu dari $18,4 \%$ pada tahun 2007 menjadi $17,9 \%$ pada tahun 2010. Provinsi Papua berdasarkan data Riskesdas tahun 2010 untuk berat badan menurut umur (BB/U) diketahui prevalensi gizi buruk sebesar 6,3\% dan gizi kurang sebesar 10\%. Dengan demikian, prevalensi gizi kurang dan buruk sebanyak 16,3\% (2), sedangkan data pemantauan status gizi (PSG) Dinas Kesehatan Kota Jayapura tahun 2008 diketahui terdapat $3,4 \%$ balita gizi buruk, $17,8 \%$ gizi kurang, $76 \%$ gizi baik, dan 2,8\% gizi lebih (3). Peta balita gizi kurang dan gizi buruk sebagian besar berada di daerah pinggiran pantai.
Masyarakat Papua mengonsumsi makanan pokok beras dan makanan pokok non beras yang merupakan bahan makanan lokal yang terdiri dari sagu, hipere atau ubi jalar, dan talas. Sagu dikonsumsi oleh sebagian masyarakat yang tinggal di pesisir pantai, hipere, dan talas dikonsumsi oleh sebagian masyarakat yang tinggal di pegunungan (4).

Sumber penghasilan rumah tangga nelayan di Distrik Jayapura Utara berasal dari perikanan laut dengan jumlah 535 dan perikanan darat sebanyak 9 rumah tangga (5). Masyarakat nelayan menempati rumah tinggal yang terbuat dari kayu dan berada di atas laut (rumah berlabuh) dengan ventilasi dan pencahayaan yang sebagian belum memenuhi syarat rumah sehat.

Komunitas yang mendominasi pekerjaan sebagai nelayan di daerah pesisir pantai yaitu masyarakat Serui dan Jayapura dari Kampung Kayo Batu (asli Papua), Bugis/Makassar dan Buton (non asli/pendatang). Masyarakat nelayan memperoleh tambahan penghasilan yang diperoleh dari berjualan pinang dan sirih, sagu dan umbi-umbian, ikan segar, ikan asap, dan hasil laut lainnya, serta sayuran dan buah. Rata-rata distribusi tingkat pendapatan per kapita keluarga nelayan sebesar Rp 407.700,-.

Harga pangan dan daya beli keluarga terkait dengan tingkat pendapatan keluarga, ketersediaan pangan di daerah setempat, serta pengetahuan ibu tentang gizi dan kesehatan dalam pemilihan bahan makanan yang berkualitas bagi keluarga. Taraf 
sosio-ekonomi dan adat kebiasaan setempat serta jumlah anggota keluarga yang banyak dalam satu rumah memegang peranan penting dalam pola konsumsi penduduk.

Melihat kondisi yang ada di lapangan, pemberdayaan yang dilakukan oleh pemerintah saat ini adalah dengan program Respek (Rencana Strategis Pembangunan Kampung). Pembangunan masyarakat Papua dimulai dari pembangunan kampong dengan peningkatan kapasitas pemerintahan kampung dan distrik. Fokus program adalah perbaikan gizi, pelayanan kesehatan, pendidikan, perumahan, ekonomi kerakyatan, dan infrastruktur kampung (6). Oleh karena itu, perlu dilakukan penelitian tentang hubungan tingkat pendapatan, pola makan, pengetahuan ibu, dan jumlah anggota keluarga dengan status gizi balita di daerah nelayan Distrik Jayapura Utara, Kota Jayapura. Tujuan penelitian ini untuk mengetahui distribusi tingkat pendapatan dan pola makan, gambaran status gizi balita, hubungan tingkat pendapatan dengan status gizi balita, dan hubungan pola makan dengan status gizi balita.

\section{BAHAN DAN METODE}

Penelitian ini merupakan penelitian cross sectional (7). Lokasi penelitian di Distrik Jayapura Utara, Kota Jayapura pada periode Oktober-Desember 2010. Populasi adalah balita berusia $12-59$ bulan. Besar sampel dihitung menggunakan rumus estimasi perbedaan dua proporsi (8). Jumlah sampel sebesar 162 balita yang dipilih secara systematic random sampling. Variabel terikat adalah status gizi, variabel bebas adalah tingkat pendapatan dan pola makan, sedangkan variabel luar yaitu pengetahuan ibu tentang gizi dan jumlah anggota keluarga.

Data penelitian diambil dengan bantuan 6 enumerator berpendidikan minimal DIII Gizi yang telah mendapat pengarahan dan pelatihan untuk menyamakan persepsi. Penelitian dilakukan dengan pengambilan data primer menggunakan kuesioner. Data tingkat pendapatan menggunakan kuesioner pengeluaran rumah tangga yang sudah divalidasi, data pola makan menggunakan food frequencyquestionnaire (FFQ) yang dimodifikasi menurut bahasa dan jenis makanan khas daerah, data pengetahuan ibu tentang gizi dan jumlah anggota keluarga menggunakan kuesioner yang telah divalidasi, sedangkan data status gizi diperoleh dengan mengukur berat badan menurut umur (BB/U) yang dibandingkan dengan standar WHO 2005. Pengolahan data status gizi dilakukan menggunakan software WHO 2005. Data karakteristik dikumpulkan melalui kuesioner dan data demografi diperoleh dari badan pusat statistik (BPS) Provinsi Papua dan BPS Kota Jayapura.

Analisis data dilakukan secara bertahap melalui analisis univariat, bivariat menggunakan chi-square, dan multivariat menggunakan uji multiple logistic regression. Pengolahan dan analisis data diawali dengan editing, coding, dan cleaning, kemudian uji statistik menggunakan program software statistic. Penelitian dilaksanakan setelah mendapat ethical clereance dari Komite Etik Fakultas Kedokteran Universitas Gadjah Mada dengan nomor: KE/FK/624/ EC tahun 2010, setelah mendapat persetujuan dan kesediaan menjadi responden dengan mengisi dan menandatangani informed consent.

\section{HASIL}

\section{Karakteristik dasar penelitian}

Subjek dalam penelitian ini berjumlah 162 balita yang berumur 12-59 bulan. Karakteristik subjek meliputi jenis kelamin dan umur balita. Karakteristik responden meliputi umur ibu, pendidikan, dan pekerjaan.

Berdasarkan Tabel 1 kategori umur, jumlah balita yang sudah mengikuti pola makan keluarga berada pada umur 12-36 bulan dan memiliki status gizi kurang berjumlah 40 anak $(64,5 \%)$. Ibu balita yang berumur $\leq 35$ tahun dan termasuk kategori gizi kurang berjumlah 56 orang (90,3\%). Pendidikan ibu pada pendidikan dasar dan memiliki balita berstatus gizi kurang, yaitu sebanyak 33 orang $(53,2 \%)$.

Pada penelitian ini, orang tua balita yang mempunyai tingkat pendapatan kurang sebanyak 51 orang $(31,5 \%)$ Terdapat pola makan kurang (jenis dan frekuensi $<3$ kali sehari) sebanyak 76 orang $(46,9 \%)$ Balita yang mempunyai status gizi kurang berjumlah 62 anak (38,3\%). 
Tabel 1. Karakteristik dasar penelitian yang dikaji berdasarkan status gizi

\begin{tabular}{|c|c|c|c|c|c|c|}
\hline \multirow{3}{*}{ Variabel } & \multicolumn{4}{|c|}{ Status gizi } & \multirow{3}{*}{$c^{2}$} & \multirow{3}{*}{$\mathbf{p}$} \\
\hline & \multicolumn{2}{|c|}{ Kurang } & \multicolumn{2}{|c|}{ Baik } & & \\
\hline & $\mathbf{n}$ & $\%$ & $\mathbf{n}$ & $\%$ & & \\
\hline \multicolumn{7}{|l|}{ Jenis kelamin balita } \\
\hline Laki-laki & 29 & 46,8 & 55 & 55,0 & 1,03 & 0,308 \\
\hline Perempuan & 33 & 53,2 & 45 & 45,0 & & \\
\hline \multicolumn{7}{|l|}{ Umur balita (bulan) } \\
\hline $12-36$ & 40 & 64,5 & 72 & 72,0 & 1,00 & 0,316 \\
\hline $37-59$ & 22 & 35,5 & 28 & 28,0 & & \\
\hline \multicolumn{7}{|l|}{ Umur ibu (tahun) } \\
\hline$\leq 35$ & 56 & 90,3 & 77 & 77,0 & 4,62 & $0,03^{\star}$ \\
\hline$>35$ & 6 & 9,7 & 23 & 23,0 & & \\
\hline \multicolumn{7}{|l|}{ Pendidikan ibu } \\
\hline Pendidikan dasar & 33 & 53,2 & 39 & 39,0 & 3,13 & $0,07^{*}$ \\
\hline Pendidikan lanjutan & 29 & 46,8 & 61 & 61,0 & & \\
\hline \multicolumn{7}{|l|}{ Pekerjaan ibu } \\
\hline Bekerja & 22 & 35,5 & 36 & 36,0 & 0,00 & 0,947 \\
\hline Tidak bekerja & 40 & 64,5 & 64 & 64,0 & & \\
\hline
\end{tabular}

Keterangan : * Variabel kandidat untuk uji multivariat $(p<0,25$; uji chi-square)

Pada variabel luar, diperoleh data pengetahuan ibu tentang gizi didapatkan dari wawancara ibu balita sebagai responden. Ibu dengan pengetahuan kurang sebanyak $57 \mathrm{ibu}(35,2 \%)$, sedangkan jumlah anggota keluarga $>4$ orang (kategori kurang) berjumlah $94(58,0 \%)$.

\section{Hubungan tingkat pendapatan dengan status gizi balita}

Setelah melakukan analisis univariat, maka dilanjutkan dengan analisis bivariat untuk melihat hubungan variabel bebas dengan variabel terikat pada Tabel 2.

Tabel 2 menunjukkan bahwa tingkat pendapatan mempunyai hubungan yang bermakna dengan status gizi balita dengan nilai $p=0,000$ $(p<0,05)$ dan $R P=4,00$. Hal ini berarti bahwa balita yang mempunyai orang tua dengan tingkat pendapatan kurang memiliki risiko 4 kali lebih besar menderita status gizi kurang dibanding dengan balita yang memiliki orang tua dengan tingkat pendapatan cukup.

\section{Hubungan pola makan dengan status gizi}

Pola makan dengan status gizi balita menunjukkan hubungan yang bermakna dengan nilai $p=0,010(p<0,05)$ dan ratio prevalence $(R P=2,31)$. Hal ini memiliki pengertian bahwa keluarga yang mempunyai pola makan kurang dari tiga kali mempunyai risiko 2,31 kali lebih besar memiliki balita yang mempunyai status gizi kurang dibanding dengan keluarga yang mempunyai pola makan baik ( $\geq 3$ kali/hari) (Tabel 3 ).

\section{Hubungan pengetahuan ibu tentang gizi dengan status gizi}

Pengetahuan ibu tentang gizi dengan status gizi balita tidak menunjukkan hubungan yang bermakna, dapat dilihat dari nilai $p=0,46(p>0,05)$ dan $R P=1,28$. Sebanyak 24 ibu (14,8\%) mempunyai pengetahuan yang kurang dan memiliki balita dengan status gizi kurang, seperti tertera pada Tabel 4.

\section{Hubungan jumlah anggota keluarga dengan status gizi}

Tabel 5 menunjukkan bahwa jumlah anggota keluarga dengan status gizi tidak memiliki hubungan yang bermakna dengan nilai $p$ sebesar 0,33 $(p>0,05)$ dan $R P=0,72$. Sebagian besar keluarga memiliki jumlah anggota $>4$ orang dengan status gizi kurang $(53,2 \%)$. 
Tabel 2. Hubungan tingkat pendapatan dengan status gizi balita

\begin{tabular}{|c|c|c|c|c|c|c|c|c|c|}
\hline \multirow{3}{*}{$\begin{array}{l}\text { Tingkat pendapatan } \\
\text { (Rp) }\end{array}$} & \multicolumn{4}{|c|}{ Kategori status gizi } & \multirow{3}{*}{$C^{2}$} & \multirow{3}{*}{$\mathbf{p}$} & \multirow{3}{*}{$\mathbf{R P}$} & \multicolumn{2}{|c|}{$95 \% \mathrm{Cl}$} \\
\hline & \multicolumn{2}{|c|}{ Kurang } & \multicolumn{2}{|c|}{ Baik } & & & & & \\
\hline & $\mathbf{n}$ & $\%$ & $\mathbf{n}$ & $\%$ & & & & Min & Maks \\
\hline Kurang (< Rp 232.989,-) & 31 & 19,1 & 20 & 12,4 & 1596 & $\cap \cap \cap \cap$ & 400 & 198 & 804 \\
\hline Cukup ( $\geq$ Rp 232.989,-) & 31 & 19,1 & 80 & 49,4 & ,96 & 0,000 & 4,00 & 1,98 & 8,04 \\
\hline
\end{tabular}

Tabel 3. Hubungan pola makan dengan status gizi

\begin{tabular}{|c|c|c|c|c|c|c|c|c|c|}
\hline \multirow{3}{*}{ Pola makan } & \multicolumn{4}{|c|}{ Kategori status gizi } & \multirow{3}{*}{$\mathrm{C}^{2}$} & \multirow{3}{*}{$\mathbf{p}$} & \multirow{3}{*}{$\mathbf{R P}$} & \multicolumn{2}{|c|}{$95 \% \mathrm{Cl}$} \\
\hline & \multicolumn{2}{|c|}{ Kurang } & \multicolumn{2}{|c|}{ Baik } & & & & & Maks \\
\hline & $\mathbf{n}$ & $\%$ & $\mathbf{n}$ & $\%$ & & & & IVIIn & IVlaks \\
\hline Kurang (<3 kali/hari) & 37 & 22,8 & 39 & 24,1 & \multirow{2}{*}{6,57} & \multirow{2}{*}{0,010} & \multirow{2}{*}{2,31} & \multirow{2}{*}{1,21} & \multirow{2}{*}{4,42} \\
\hline Baik ( $(\geq 3$ kali/hari) & 25 & 15,4 & 61 & 37,7 & & & & & \\
\hline
\end{tabular}

Tabel 4. Hubungan pengetahuan ibu tentang gizi dengan status gizi

\begin{tabular}{|c|c|c|c|c|c|c|c|c|c|}
\hline \multirow{3}{*}{ Pengetahuan } & \multicolumn{4}{|c|}{ Kategori status gizi } & \multirow{3}{*}{$\mathrm{C}^{2}$} & \multirow{3}{*}{$\mathbf{p}$} & \multirow{3}{*}{$\mathbf{R P}$} & \multicolumn{2}{|c|}{$95 \% \mathrm{Cl}$} \\
\hline & \multicolumn{2}{|c|}{ Kurang } & \multicolumn{2}{|c|}{ Baik } & & & & & \\
\hline & $n$ & $\%$ & $\mathbf{n}$ & $\%$ & & & & Min & Maks \\
\hline Kurang $(<80)$ & 24 & 14,8 & 33 & 20,3 & \multirow{2}{*}{0,54} & \multirow{2}{*}{0,46} & \multirow{2}{*}{1,28} & \multirow{2}{*}{0,66} & \multirow{2}{*}{2,48} \\
\hline Baik $(\geq 80)$ & 38 & 23,4 & 67 & 41,5 & & & & & \\
\hline
\end{tabular}

Tabel 5. Hubungan jumlah anggota keluarga dengan status gizi

\begin{tabular}{|c|c|c|c|c|c|c|c|c|c|}
\hline \multirow{3}{*}{ Pengetahuan } & \multicolumn{4}{|c|}{ Kategori status gizi } & \multirow{3}{*}{$\mathrm{C}^{2}$} & \multirow{3}{*}{$\mathbf{p}$} & \multirow{3}{*}{$\mathbf{R P}$} & \multicolumn{2}{|c|}{$95 \% \mathrm{Cl}$} \\
\hline & \multicolumn{2}{|c|}{ Kurang } & \multicolumn{2}{|c|}{ Baik } & & & & Min & Maks \\
\hline & $\mathbf{n}$ & $\%$ & $\mathbf{n}$ & $\%$ & & & & IVIIn & IVIaks \\
\hline Kurang (>4 orang) & 33 & 53,2 & 61 & 61,0 & 095 & 033 & 072 & 038 & 138 \\
\hline Baik $\quad(\leq 4$ orang $)$ & 29 & 46,8 & 39 & 39,0 & 0,95 & 0,33 & 12 & 0,30 & 1,38 \\
\hline
\end{tabular}

\section{Analisis multivariat}

Analisis multivariat dilakukan untuk melihat variabel yang lebih dominan. Dalam penelitian ini, tingkat pendapatan, pola makan, umur ibu dan pendidikan ibu mempunyai hubungan yang bermakna dengan status gizi balita. Sehingga analisis dilanjutkan pada analisis multivariat menggunakan uji multiple logistic regression atau regresi logistik ganda, seperti tertera pada Tabel 6.

Tahapan yang dilakukan pada analisis multivariat untuk mendapatkan model terpilih terbagi dalam 2 step (langkah). Pada step 1, variabel yang dimasukkan adalah tingkat pendapatan, pola makan, pendidikan ibu, dan umur ibu. Variabel yang bermakna dilanjutkan pada step 2 untuk memilih model yang terbaik, yaitu tingkat pendapatan, pendidikan ibu, dan umur ibu.

Tingkat pendapatan dan umur ibu memiliki hubungan yang bermakna $(p<0,25)$ dengan nilai Exp
( $\beta$ ) adalah 4,35 dan 3,48. Variabel yang dominan memiliki hubungan dengan status gizi adalah tingkat pendapatan, artinya balita yang mempunyai orang tua dengan tingkat pendapatan kurang memiliki risiko 4,35 kali lebih besar terkena status gizi kurang dibanding dengan balita yang mempunyai orang tua dengan tingkat pendapatan cukup.

\section{BAHASAN}

Berdasarkan hasil analisis tingkat pendapatan orang tua dengan status gizi balita, memiliki hubungan yang bermakna terlihat dari nilai $p=0,000$ $(p<0,05)$ dengan $R P=4,00$ pada analisa bivariat. Hal ini berarti balita yang mempunyai orang tua dengan tingkat pendapatan kurang memiliki risiko 4 kali lebih besar terkena status gizi kurang dibanding dengan balita yang memiliki orang tua dengan tingkat pendapatan cukup. Penelitian ini sejalan dengan penelitian lain di Kecamatan Mandai 
Tabel 6. Analisis multivariat

\begin{tabular}{|c|c|c|c|c|c|c|}
\hline \multirow{2}{*}{ Variabel } & \multirow{2}{*}{$\beta$} & \multirow{2}{*}{ SE } & \multirow{2}{*}{ p } & \multirow{2}{*}{$\operatorname{Exp}(\beta)$} & \multicolumn{2}{|c|}{$95 \% \mathrm{Cl}$} \\
\hline & & & & & Min & Maks \\
\hline Model yang dipilih & & & & & & \\
\hline $\begin{array}{l}\text { Tingkat Pendapatan } \\
\text { Kurang } \\
\text { Cukup (R) }\end{array}$ & 1,47 & 0,37 & $0,000^{*}$ & 4,35 & 2,09 & 9,03 \\
\hline $\begin{array}{l}\text { Umur ibu } \\
\quad \leq 35 \text { tahun } \\
\quad>35 \text { tahun }(\mathrm{R})\end{array}$ & 1,24 & 0,53 & $0,019^{*}$ & 3,48 & 1,23 & 9,86 \\
\hline
\end{tabular}

Keterangan: (R) Kelompok referensi

Kabupaten Maros yang menunjukkan hubungan yang bermakna antara tingkat pendapatan keluarga dengan status gizi balita (9). Penelitian di Afrika menemukan hubungan yang bermakna antara tingkat pendapatan dengan status gizi, prevalensi gizi kurang menurun secara nyata ketika pendapatan meningkat (10). Pada penelitian lainnya juga dibuktikan hubungan yang bermakna antara pendapatan keluarga dengan kejadian gizi buruk (11). Pendapatan keluarga terkait dengan pembelian dan pemilihan bahan makanan. Anak yang tidak cukup makan, daya tahan tubuhnya (imunitas) dapat melemah. Dalam keadaan demikian, anak mudah diserang infeksi, kurang nafsu makan, dan akhirnya rentan terhadap kurang gizi.

Variabel lainnya adalah pola makan dengan status gizi memiliki hubungan yang bermakna dengan nilai $p=0,010(p<0,05)$ dan $R P=2,31$, artinya balita yang mempunyai pola makan kurang dari 3 kali sehari berisiko 2,31 kali menjadi status gizi kurang. Penelitian di Jambi tentang pola makan anak, asupan zat gizi, dan status gizi balita dilihat dari jenisnya $54,2 \%$ sudah berada dalam kategori lengkap dalam pola makan dan jika dilihat dari frekuensi makannya $52,1 \%$ berada dalam kategori baik (12).

Pengetahuan merupakan salah satu domain yang akan mempengaruhi perilaku seseorang (13). Pengetahuan ibu tentang gizi yang merupakan variabel luar pada penelitian ini dengan status gizi balita tidak menunjukkan hubungan yang bermakna dengan nilai $p=0,46(p>0,05)$ dan $R P=1,28$, meskipun jumlah ibu yang memiliki pengetahuan baik lebih banyak $(41,5 \%)$ daripada ibu yang memiliki pengetahuan kurang. Penelitian lain di Indragiri Hilir yang sejalan dengan penelitian ini yang menunjukkan tidak ada perbedaan pengetahuan pada kelompok ibu-ibu yang anaknya tidak mendapatkan pendidikan gizi di sekolah (14). Pengetahuan gizi yang dimiliki mempunyai hubungan positif dalam memilah-milah bahan makanan yang akan diberikan kepada anak (9). Penelitian di Asia Pasifik menjelaskan bahwa pengetahuan gizi merupakan faktor yang cukup penting, namun bukan untuk perubahan perilaku konsumen makanan. Pengetahuan gizi berpengaruh kecil, tetapi penting dalam penerapan kebiasaan makanan sehat. Pengetahuan adalah bagian dari sistem yang terbuka. Konsumen akan menerjemahkan pengetahuan itu dan melakukan hal-hal yang mereka suka (15). Sebaliknya, penelitian lain di Langkat tahun 2005 menunjukkan hubungan yang bermakna antara pengetahuan ibu dengan status gizi balita. Semakin tinggi pengetahuan dan banyaknya pengalaman, semakin bervariasi ibu menyediakan makanan bagi balitanya sehingga kualitas dan kuantitas makanan yang disajikan mempunyai nilai gizi yang tinggi (16).

Pada penelitian ini, jumlah anggota keluarga tidak menunjukkan hubungan yang bermakna dengan nilai $p=0,33(p>0,05)$. Penelitian di wilayah pesisir Jawa Barat tahun 2008 hingga 2009 meneliti bahwa besar keluarga tidak berpengaruh terhadap kesejahteraan keluarga nelayan dengan menggunakan kriteria World Bank, Badan Pusat Statistik (BPS), Badan Koordinasi Keluarga Keluarga Berencana Nasional (BKKBN), dan Bantuan Langsung Tunai (BLT) dengan jumlah anggota keluarga inti (<4). Keluarga dengan jumlah anggota keluarga yang lebih sedikit memiliki peluang untuk lebih sejahtera dibanding dengan 
yang memiliki jumlah anggota keluarga yang lebih besar (17). Penelitian ini sejalan dengan penelitian di Langkat, Sumatera Barat tahun 2001 yang menunjukkan tidak ada perbedaan bermakna antara proporsi balita kurang energi protein (KEP) dengan jumlah anggota keluarga $(p=0,531)(18)$. Berbeda dengan penelitian di Lombok Barat tahun 2007 menunjukkan bahwa jumlah anggota keluarga berpengaruh signifikan terhadap aspek dominan pola asuh. Hal ini berarti semakin kecil jumlah anggota keluarga, ibu mempunyai waktu yang lebih banyak untuk mengasuh anak sehingga tumbuh kembang anak dapat dipantau dan anak terhindar dari status gizi kurang dan buruk (19). Pendidikan merupakan aspek penting dalam menunjang kualitas manusia, seperti tersirat dalam indeks pembangunan manusia (IPM) (20). Penelitian lain di Ghana menyebutkan bahwa pengetahuan gizi ibu secara bebas berhubungan dengan status gizi setelah mengontrol efek dari variabel-variabel lain yang bermakna. Pendidikan ibu di sisi lain tidak ditemukan secara bebas berhubungan dengan status gizi, artinya bahwa pengetahuan praktis ibu tentang gizi lebih penting daripada pendidikan formal ibu untuk status gizi anak (21).

Pada analisis multivariat, variabel yang dimasukkan adalah yang memiliki nilai $p<0,25$. Yang termasuk dalam analisis ini yaitu tingkat pendapatan, pola makan, umur ibu, dan pendidikan ibu, sehingga analisis dilanjutkan pada analisis multivariat menggunakan uji multiple logistic regression atau regresi logistik ganda. Pada analisis multivariat, variabel tingkat pendapatan, pola makan, umur ibu, dan pendidikan ibu bukan merupakan variabel dominan. Penelitian di Tembalang menunjukkan tidak ada hubungan antara umur ibu dengan status gizi balita. Hal ini terjadi karena kemungkinan kelompok umur ibu memiliki pola asuh yang hampir sama dan berasal dari keluarga dengan status sosial ekonomi yang sama (22). Variabel yang paling dominan memiliki hubungan dengan status gizi adalah tingkat pendapatan dengan $\mathrm{RP}=4,35$. Hal ini bahwa balita yang mempunyai orang tua dengan tingkat pendapatan kurang mempunyai risiko 4,35 kali lebih besar terkena status gizi kurang dibanding balita yang memiliki tingkat pendapatan cukup.
Variabel luar lainnya adalah pengetahuan ibu tentang gizi dengan status gizi dan jumlah anggota keluarga dengan status gizi tidak menunjukkan hubungan yang bermakna. Pengetahuan ibu yang rendah berada pada domain kognitif tingkat memahami, aplikasi dan analisis. Faktor penguat yaitu sikap dan perilaku tokoh masyarakat/tokoh agama/tokoh adat dan petugas kesehatan, sehingga dengan melihat contoh menyebabkan pola pikir dan wawasan pengetahuan ibu lebih berkembang.

\section{KESIMPULAN DAN SARAN}

Rata-rata distribusi tingkat pendapatan per kapita keluarga nelayan sebesar Rp 407.700,-Balita yang mempunyai orang tua dengan tingkat pendapatan cukup memiliki status gizi yang lebih baik dibanding dengan balita yang mempunyai orang tua dengan tingkat pendapatan kurang. Balita yang mempunyai pola makan cukup memiliki status gizi yang lebih baik dibanding dengan balita yang mempunyai pola makan kurang.

Untuk meningkatkan pendapatan keluarga, diharapkan kepada Dinas Kesehatan dan Dinas Perikanan dapat memberikan pelatihan melalui teknologi tepat guna sehingga meningkatkan pengetahuan dan keterampilan masyarakat tentang pengolahan, penyimpanan/pengawetan makanan agar tersedia makanan berbahan dasar ikan dan hasil olahannya dalam jumlah cukup dan daya simpan yang lama sehingga dapat menjadi sumber pendapatan.

Untuk meningkatkan pola makan, diharapkan kepada Dinas Kesehatan, Dinas Pemberdayaan Perempuan, Pemerintah Distrik, dan PKK secara rutin dan berkala memberikan penyuluhan berupa komunikasi, informasi, dan edukasi gizi (KIE gizi) agar masyarakat memiliki pemahaman yang benar tentang triguna makanan, jenis, dan frekuensi makan dalam konsep sosio-budaya dan kesehatan.

\section{RUJUKAN}

1. Departemen Kesehatan Repuplik Indonesia. Pedoman umum pemberian makanan pendamping air susu ibu (MP-ASI) lokal. Jakarta: Departemen Kesehatan Rl; 2006. 
2. Departemen Kesehatan Repuplik Indonesia. Data riset kesehatan dasar (Riskesdas) 2010 [Internet]. Jakarta: Balai Penelitian dan Pengembangan Kesehatan RI; 2010. Available from: http://www.litbang.depkes.go.id

3. Jayapura DKK. Pemantauan status gizi. Jayapura: Dinas Kesehatan Kota Jayapura; 2008.

4. Ayomi C, Mampioper. Konsumsi pangan lokal di Papua rendah [Internet]. 2008 [cited 2008 Apr 28]. Available from: $h$ ttp://tabloidjubi.wordpress. com

5. Badan Pusat Statistik Kota Jayapura. Jayapura dalam angka. Jayapura: BPS Kota Jayapura; 2010.

6. Suebu B. Kami menanam, kami menyiram, Tuhanlah yang menumbuhkan. Jayapura: Pemerintah Provinsi Papua, Jayapura; 2007.

7. Nugroho S. Besar sampel dalam penelitian kesehatan. Yogyakarta: Digibooks; 2010.

8. Lemeshow S, Hosmer D, Klar J, Lwanga S. Besar sampel dalam penelitian kesehatan. Yogyakarta: Gadjah Mada University Press; 1997.

9. Khaeriyah. Hubungan tingkat konsumsi energi dan protein dengan status gizi balita di Kelurahan Persiapan Bontoa Kecamatan Mandai Kabupaten Maros. J Med Nusant. 2001;22(4):468-89.

10. Salah E, Mahgoub, Nnyepi M, Teori Theodore B. Factors affecting of malnutrition among children under three years of age in Botswana, African. J Food Agric Nutr Dev. 2006;6(1):1-15.

11. Anwar, K, Juffrie $M$, Julia M. Faktor risiko kejadian gizi buruk di Kabupaten Lombok Timur, Provinsi Nusa Tenggara Barat. J Gizi Klin Indones. 2006;2(3):108-16.

12. Erni, Juffrie M, Rialihanto M. Pola makan, asupan zat gizi, dan status gizi anak balita Suku Anak Dalam di Nyogan Kabupaten Muaro
Jambi Provinsi Jambi. J Gizi Klin Indones. 2008;5(2):84-90.

13. Notoatmodjo $S$. Kesehatan masyarakat ilmu dan seni. Jakarta: Rineka Cipta; 2007.

14. Zulkarnaini, Toto $S$, Untung S. Pengaruh pendidikan gizi pada murid sekolah dasar terhadap peningkatan pengetahuan, sikap, dan perilaku ibu keluarga mandiri sadar gizi di Kabupaten Indragiri Hilir. J Gizi Klin Indones. 2006;3(1):29-33.

15. Worsley A. Nutrition knowledge and food consumption: can nutrition knowledge change food behaviour? Asia Pasific J Clin Nutr. 2002;11:S579-85.

16. Mardiana. Hubungan perilaku gizi ibu dengan status gizi balita di Puskesmas Tanjung Beringin Kecamatan Hinai Kabupaten Langkat 2006. Universitas Sumatera Utara; 2006.

17. Istiqlaliyah M, Hartoyo, Ujang S, Achmad F, Herien P. Kondisi sosial ekonomi dan tingkat kesejahteraan keluarga: kasus di Wilayah Pesisir Jawa Barat. J IIm Kel Konsum. 2010;3(1):1-10.

18. Orisinal. Faktor-faktor yang berhubungan dengan status gizi balita di Sumatera Barat tahun 2001. Universitas Indonesia; 2003.

19. Luh S, Chandradewi. Studi tentang karakteristik keluarga dan pola asuh pada balita gizi kurang dan gizi buruk di Kabupaten Lombok Barat. J Kesehat Prima. 2008;2(2):296-303.

20. Sekretariat Negara RI. Indeks pembangunan manusia Indonesia. Jakarta: Sekretariat Negara RI; 2007.

21. Yaa A, Sturla K. Maternal nutrition knowledge and child nutritional status in the Volta Region Ghana. Matern Child Nutr. 2005;1(2):100-10.

22. Meikawati, W, Hersoelistyorini W. Hubungan karakteristik ibu dan tingkat sosial ekonomi keluarga terhadap kasus gizi buruk pada balita di Kelurahan Tandang Kecamatan Tembalang. J Unimus. 2008;1(1):148-57. 